\begin{tabular}{|c|c|c|c|}
\hline T H E & A R C H I V E & M E C H A N I C A L & E N G I N E E R I N G \\
\hline VOL. LIX & & 2012 & Number 2 \\
\hline $10.2478 / \mathrm{v} 1$ & $80-012-0011-4$ & & \\
\hline
\end{tabular}

$J A N R Y S^{*}$

\title{
THE PROCEDURE OF MODIFICATION COEFFICIENTS IN PLANETARY GEAR TRANSMISSION
}

\begin{abstract}
The aim of this article is to present the design procedure for determining modification coefficients of toothed wheels of involutes planetary gear train with internal conjunction of teeth. It is possible to obtain a higher load-carrying capacity which depends also on correction coefficients. For example, we take into consideration a concept of planetary gears in which the teeth can be corrected, which allows better fatigue and contact surface strength.

Two cases are considered when the namely zero center distance (without corrections) of the central and satellite wheels is the same or not, in relation to the zero center distance between the satellite and the sun wheel.

Geometrical dimensions are described with regard to the technological teeth correction scope, and inequality restriction conditions are determined with respect to the ISO standards recommendations and the literature. The procedure can be applied to any other planetary gears with another kinematic connection of wheels.
\end{abstract}

\section{Fundamental design relation and restrictions of planetary gears}

The scheme of a stage planetary gear with correction coefficients is shown in Fig. 1. The basic mechanical configuration consists of two cooperating pairs of gears with the same distance of the rotation axis. We assume that the tools which generate the teeth have the module " $m$ ", the profile angle " $\alpha$ ", the addendum factor $\mathrm{y}=1$ and the tip clearance factor $\mathrm{c}_{o}=0.25$.

On the basis of a standard rack, cutting tools can generate toothed wheels with different coefficients of corrections. Under these assumptions, the radii of the rolling circle are different then the radii of the pitch diameters and the pressure angle of the co-operating teeth $\mathrm{z}_{1} / \mathrm{z}_{2}$ and $\mathrm{z}_{2} / \mathrm{z}_{3}$ are different then

* Cracow University of Technology, Faculty of the Mechanical Engineering, Chair Fundamentals of Machine Design, Institute of Machine Design (M-3). Al. Jana Pawla II 37, 31-864 Krakow, Poland; e-mail: szymon@mech.pk.edu.pl 
the profile angle of the tools. In some cases it is possible when the pressure angles $\alpha_{w}{ }^{\prime \prime} \neq \alpha_{w}{ }^{\prime}$, as indicated in Fig. 1, that the satellite wheel has one radius of the pitch diametric circle, but it has got a pair of rolling circles with the radii $\mathrm{r}_{w}$ " and $\mathrm{r}_{w}$ ". the Superscripts (") determine the data for the toothed wheels $z_{1} / z_{2}$, and the superscripts (") determine the data for the toothed wheels $z_{2} / z_{3}$.

An example of a gearbox project is presented in Fig. 2, where the central wheel $z_{1}$ working without bearings (the floating wheel-9) and the selfaligning bearings (32) of satellites $\mathrm{z}_{2}$ guarantee uniform redistribution load to each satellite wheel (11).

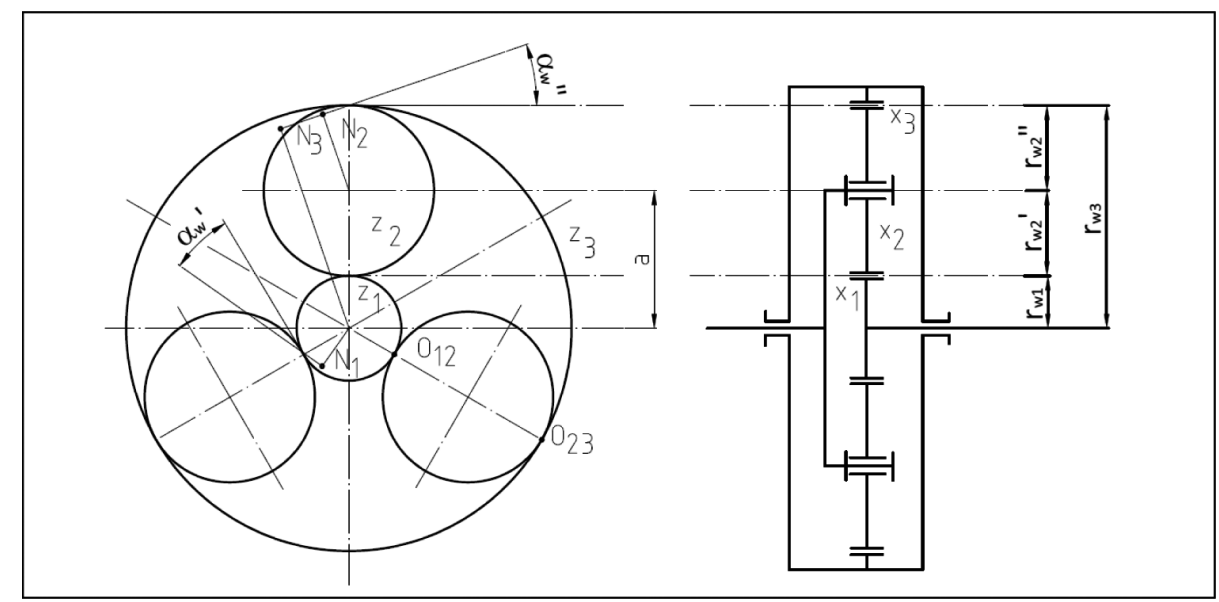

Fig. 1. Geometric diagram of a one stage planetary gear with correction coefficients

If we know the corrections coefficients modification $\mathrm{x}_{1} ; \mathrm{x}_{2} ; \mathrm{x}_{3}$, then the proportions of toothed engagements in a circumferential cross-section can be found from the formulas presented in literature [1],[3]. The factor " $x$ " changes the relative proportions of the teeth, since the actual shift of the tool $\mathrm{r}$ in relation to the blank equal " $\mathrm{X}=\mathrm{x} * \mathrm{~m}$ " changes too at the moment the cutting process is completed. The displacement " $\mathrm{X}$ " is a distance between the pitch circle of the cutting wheel and the pitch circle or the pitch line of the tool, the sign of " $\mathrm{x}$ is positive when displacement " $\mathrm{X}$ " is outside of material of the cutting wheel in relation to the central point during the cutting process; otherwise, it is negative.

On account of the proper assembly, it is necessary to set the satellite wheels symmetrically in relation to the central and the sun wheel. A correct distance between the addendum circles of the neighboring satellites requires satisfying some restrictions as to the proper number of teeth $\mathrm{z}_{1} ; \mathrm{z}_{2} ; \mathrm{z}_{3}$ and the number of satellite wheels as it was presented in [1],[2]. 


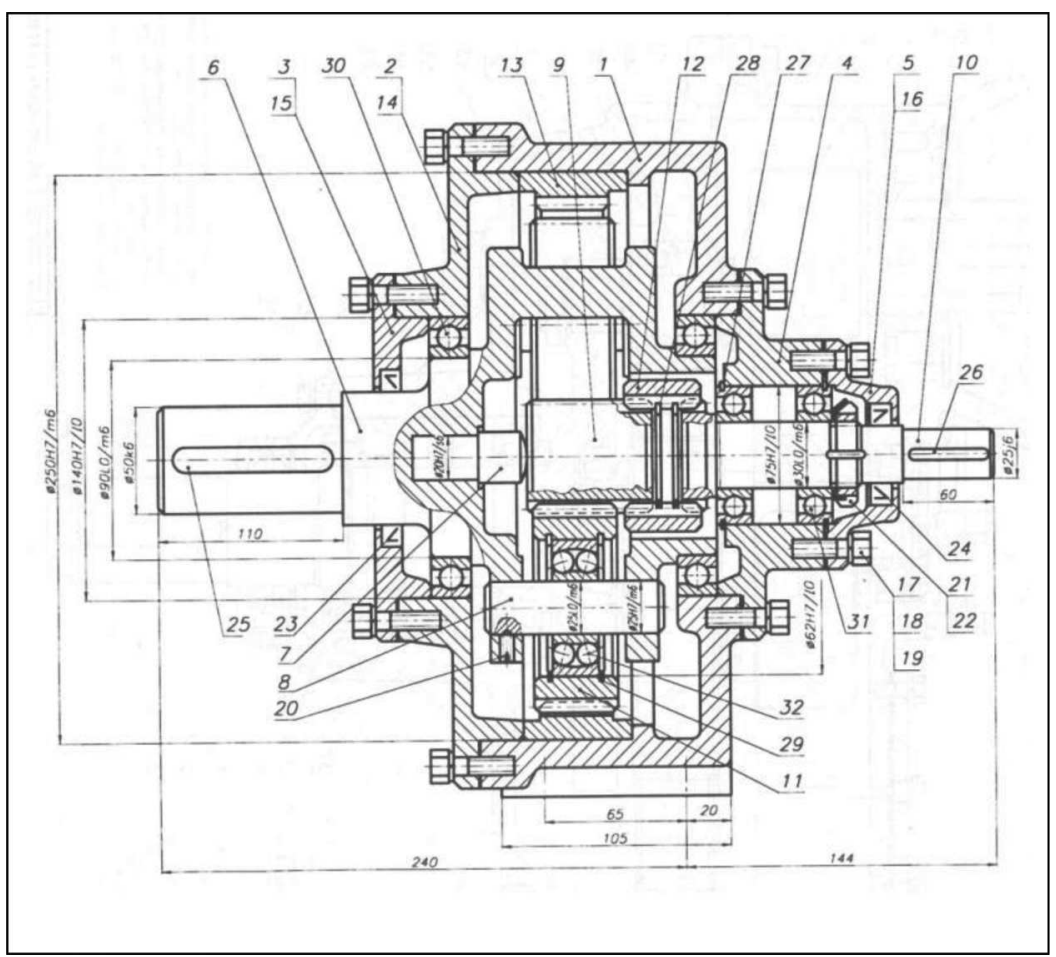

Fig. 2. Structure of a one stage planetary gearbox with 3 satellite wheels

The next important problem is connected with noninterference internal engagements of the satellites and the sun wheel, which requires taking into account the changing geometry caused by corrections coefficients. The condition of noninterference located on the dedendum circle of the satellite wheel [2] is

$$
z_{2}>z_{3} \cdot\left\{1-\sqrt{1-\frac{1}{\sin ^{2} \alpha_{w}^{\prime \prime}}\left[1-\left(\frac{r_{a 3}}{r_{w 3}}\right)^{2}\right]}\right\}
$$

where: $\mathrm{r}_{a 3}$ - the addendum radius of the sun wheel, $\mathrm{r}_{w 3}$ - the radius of the rolling circle of the sun wheel. On the basis of the formula (1) Fig. 3 shows the relations $\mathrm{z}_{2}>\mathrm{z}_{2}\left(\mathrm{z}_{3}\right)$ which secures noninterference located on the addendum circle of the satellite wheel [3], [7] when $\mathrm{x}_{2}=\mathrm{x}_{3}=0$.

Mathematical notation of the condition of noninterference located on the addendum circle of the satellite wheel [2] is more complicated:

$$
\begin{gathered}
\phi_{3}-\vartheta_{3}<\left(\phi_{2}+\vartheta_{2}\right) \cdot \frac{z_{2}}{z_{3}} \\
\phi_{3}=\operatorname{arcos} \frac{r_{a 3}^{2}-r_{a 2}^{2}+a_{w}^{2}}{2 \cdot a_{w} \cdot r_{a 3}} ; \phi_{2}=\operatorname{arcos} \frac{r_{a 3}^{2}-r_{a 2}^{2}-a_{w}^{2}}{2 \cdot a_{w} \cdot r_{a 2}}
\end{gathered}
$$




$$
\begin{gathered}
\vartheta_{3}=\operatorname{inv}\left(\alpha_{w}^{\prime \prime}\right)-\operatorname{inv}\left[\operatorname{arcos}\left(\frac{r_{b 3}}{r_{a 3}}\right)\right] ; \vartheta_{2}=\operatorname{inv}\left[\operatorname{arcos}\left(\frac{r_{b 2}}{r_{a 2}}\right)\right]-\operatorname{inv}\left(\alpha_{w}^{\prime \prime}\right) \\
a_{w}=0.5\left(z_{3}-z_{2}\right) m_{w}^{\prime \prime}
\end{gathered}
$$

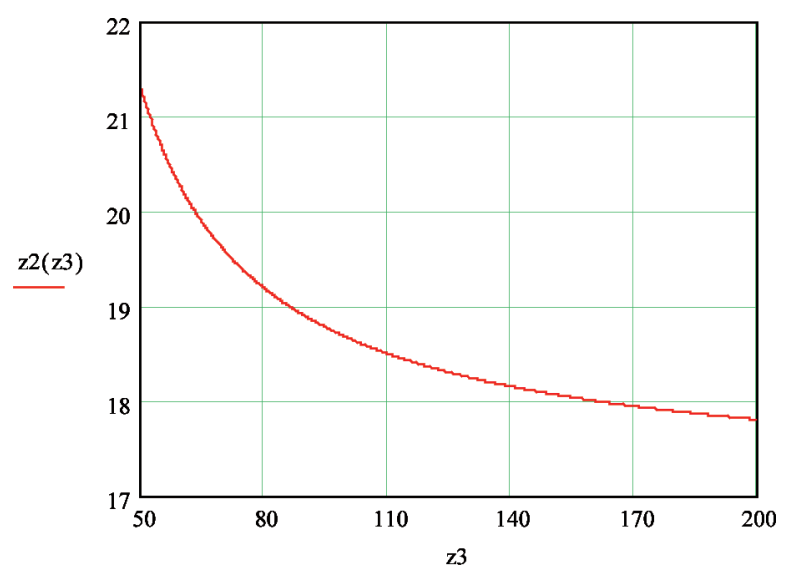

Fig. 3. Minimal number of satellites teeth $\mathrm{z}_{2}, \mathrm{y}=1, \alpha=20^{\circ}$

The inequality (1) and (2) must be verified when the dimensions of the toothed wheels have been defined.

\section{Valuable limit of coefficient of corrections " $x "$}

The original designs of the conjunction of the toothed wheels must satisfy Fölmer's equations by the relations.

$$
\begin{aligned}
& x_{1}+x_{2}=C 1=\frac{\left\{\left[\tan \left(\alpha_{w}^{\prime}\right)-\alpha_{w}^{\prime}\right]-\tan (\alpha)+\alpha\right\} \cdot\left(z_{1}+z_{2}\right)}{2 \cdot \tan (\alpha)} \\
& x_{2}+x_{3}=C 2=\frac{\left\{\left[\tan \left(\alpha_{w}^{\prime \prime}\right)-\alpha_{w}^{\prime \prime}\right]-\tan (\alpha)+\alpha\right\} \cdot\left(z_{2}-z_{3}\right)}{2 \cdot \tan (\alpha)}
\end{aligned}
$$

where: $x_{1} ; x_{2} ; x_{3}$ - correction coefficients modification, $z_{1} ; z_{2} ; z_{3}-$ the number of teeth of the central, satellite and sun wheels, $\alpha$ - the profile angle of tools (e.g. for a sun wheel gear-shaper cutter - Fellows on slotting machine). If $x_{1}=x_{2}=x_{3}=0$, then the planetary gear is without correction modifications, in addition, when $x_{1}+x_{2}=0 \wedge x_{3}+x_{2}=0$, we have the corrections named $\mathrm{P} 0$; and in both of these cases the pressure angle, according to Fig. $1, \alpha_{w}{ }^{\prime}{ }^{\prime}=\alpha_{w}{ }^{6}=\alpha$, and the coefficients $\mathrm{C} 1=\mathrm{C} 2=0$. When $\mathrm{C} 1 \neq 0$ and $\mathrm{C} 2 \neq 0$ the corrections has the name $\mathrm{P}$.

For each wheel of external conjunction with $\mathrm{z}_{1}$ and $\mathrm{z}_{2}$, the correction coefficient is limited by: no-undercutting condition, minimal thickness of teeth 
greater than $0.3^{*} \mathrm{~m}$ in the radius of the addendum circle $\mathrm{r}_{a}$ (tooth thickness at the top), the radius of the diametric pitch " $\mathrm{r}$ " is in the measuring zone $\mathrm{r}_{a}>\mathrm{r}>\mathrm{r}_{f}-\mathrm{c}, \mathrm{c}=\mathrm{c}_{o} * \mathrm{~m}, \mathrm{r}_{f}-$ the radius of the dedendum circle.

$$
\begin{gathered}
x \leq \frac{19}{289}+10 \cdot \frac{z}{289} \text { for } 10 \leq z \leq 24 \wedge x \leq 1 \text { for } z \geq 25 \\
x \geq 1-\frac{z}{17} \text { for } 10 \leq z \leq 32 \wedge x \geq-0.9 \text { for } z \geq 33
\end{gathered}
$$

For the sun wheel $z_{3}$ when $z_{3}>30$ the corrections coefficient should be

$$
0.5 \geq x_{3} \geq-0.5 \text { for } z_{3} \geq 65
$$

For all these reasons, corrections coefficients have been limited and geometric parameters are not identical; that is why it is possible to obtain a higher loadcarrying capacity which depends also on correction coefficients.

The application of proper correction coefficients gives us the possibility to find a better fatigue and contact strength of the cooperating teeth.

Let us consider two cases:

Case I, when $z_{1}+z_{2}=z_{3}-Z_{2}$, the zero center distances of wheels are the same,

Case II, when $z_{1}+z_{2} \neq z_{3}-z_{2}$, the zero center distances of wheels are different.

In these cases, the solutions of geometry are different when one applies a rational method of achieving better strength in each separate case. The example of a planetary gear in both cases is presented in Fig. 4. The satellite wheels are located symmetrically in relation to the central and the sun wheel with a correct distance between the addendum circles of the neighboring satellites, at the same time, some restrictions concerning the proper number of teeth $\mathrm{z}_{1} ; \mathrm{z}_{2} ; \mathrm{z}_{3}$ are satisfied.

According to Fig. 1, the constant center distance "a" of the wheels forces the pressure angles $\alpha_{w}^{\prime \prime}$ and $\alpha_{w}^{\prime}$ which are given by

$$
\cos \alpha_{w}^{\prime}=\frac{2 \cdot a}{z_{1}+z_{2}} \cos \alpha, \cos \alpha_{w}^{\prime \prime}=\frac{2 \cdot a}{z_{3}-z_{2}} \cos \alpha
$$

In case $I$, when $\mathrm{z}_{1}+\mathrm{z}_{2}=\mathrm{z}_{3}-\mathrm{Z}_{2}$, the zero center distances of the wheels are the same, then $\alpha_{w}^{\prime \prime}=\alpha_{w}^{\prime}=\alpha_{w}$, and in accordance with (4) $\mathrm{C} 1=-\mathrm{C} 2=\mathrm{C}$, the relations between the corrections coefficients are limited by (9)

$$
x_{1}+x_{2}=C ; x_{2}+x_{3}=-C
$$




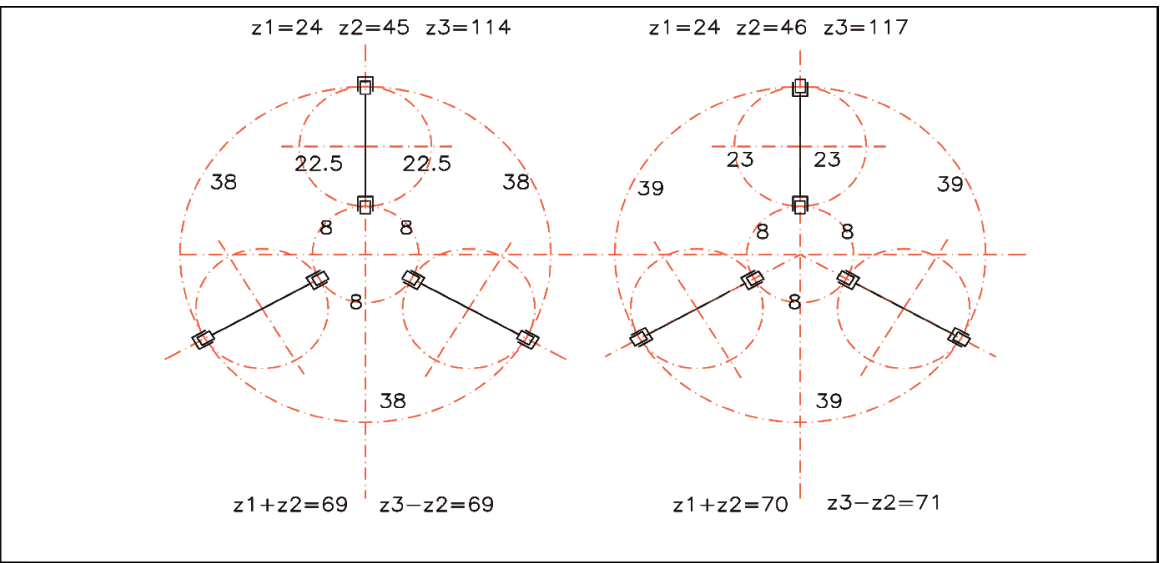

Fig. 4. Case I, when $z_{1}+z_{2}=z_{3}-z_{2}$, the same zero center distance central/ satellite and satellite, /sun wheel. Case II, when $z_{1}+z_{2} \neq z_{3}-z_{2}$, zero center distance of wheels are different

If we do not take the correction type P0 into account, then assuming the value of $\mathrm{x}_{2}$ we obtain other correction factors

$$
\begin{aligned}
& x_{1}=C-x_{2} \wedge x_{3}=-C-x_{2} \Rightarrow x_{1}-x_{3}=2 \cdot C \\
& r_{w 2}^{\prime}=0.5 \cdot z_{2} \cdot \frac{\cos \alpha}{\cos \alpha_{w}^{\prime}} ; r_{w 2}^{\prime \prime}=0.5 \cdot z_{2} \cdot \frac{\cos \alpha}{\cos \alpha_{w}^{\prime \prime}} \\
& r_{w 2}^{\prime}=r_{w 2}^{\prime \prime}=r_{w 2}
\end{aligned}
$$

In case II, when $\mathrm{z}_{1}+\mathrm{z}_{2} \neq \mathrm{Z}_{3}-\mathrm{Z}_{2}$, the zero center distances of the wheels are the different, then $\alpha_{w}^{\prime \prime} \neq \alpha_{w}^{\prime}$, and in accordance with (4) $\mathrm{C} 1 \neq \mathrm{C} 2$ the relations between the corrections coefficients are limited by equations

$$
\begin{aligned}
& x_{1}+x_{2}=C 1, x_{2}-x_{3}=C 2 \\
& r_{w 2}^{\prime}=0.5 \cdot z_{2} \cdot \frac{\cos \alpha}{\cos \alpha_{w}^{c}} ; r_{w 2}^{\prime \prime}=0.5 \cdot z_{2} \cdot \frac{\cos \alpha}{\cos \alpha_{w}^{\prime c}} . \\
& r_{w 2}^{\prime} \neq r_{w 2}^{*}
\end{aligned}
$$

Then the satellite wheel has one radius of the pitch diametric circle but it has a pair of rolling circles with the radii' $\mathrm{r}_{w}{ }^{\prime}$ and $\mathrm{r}_{w}{ }^{\prime}$.

The formulas for determining the main dimensions describe the conjunctions of the teeth without backlash (pitch play). In the cutting process of the satellite we have to decrease the correction factor $x_{2}$, in order to obtain the operational backlash value $\mathrm{L}_{b}$ expressed by the following formula for amendment $\Delta \mathrm{x}_{2}$.

$$
\Delta x_{2}=\frac{-2 \cdot L_{b}}{m \cdot \sin \alpha}
$$




\section{Main criteria of fatigue and surface strength}

In engineering practice, we use the following ISO [4] formulas to compute the fatigue stresses at the root of teeth $\sigma_{F}$ and surface fatigue stresses $\sigma_{H}$ in the zone of one pair of contact teeth,

$$
\begin{gathered}
\sigma_{F 1,2}=\frac{F_{t} K_{F}}{b_{w} m_{n}} Y_{\mathrm{FS} 1,2} Y_{\varepsilon} Y_{\beta} \leq \sigma_{\mathrm{FP}}, \\
\sigma_{H}=Z_{E} Z_{H} Z_{\varepsilon} Z_{\beta} \sqrt{\frac{F_{t} K_{H}}{b_{w} d_{1}} \frac{u+1}{u}} \leq \sigma_{\mathrm{HP}},
\end{gathered}
$$

where: $\sigma_{F P}-$ is the allowable stress at the root, $\sigma_{H P}-$ is the allowable surface stress, $\mathrm{F}_{t}-$ is the nominal circumferential load of the cooperating wheels, $\mathrm{b}_{w}$ - the width of the wheels, $\mathrm{d}_{1}-$ the pitch diameter of a pinion, $\mathrm{m}_{n}-$ the gear module of the pair of cooperating teeth. The calculation variables $\mathrm{K}_{F}$, $\mathrm{K}_{H}, \mathrm{Y}_{F S}, \mathrm{Y}_{\varepsilon}, \mathrm{Y}_{\beta}, \mathrm{Z}_{H}, \mathrm{Z}_{E}, \mathrm{Z}_{\varepsilon}, \mathrm{Z}_{\beta}$ and allowable stresses from the formulas (13), (14) are defined in [4].

The fatigue stresses at the root of teeth $\sigma_{F}$ and surface fatigue stresses $\sigma_{H}$ depend on relations $Y_{F S}(x, z), Z_{H}\left(\rho_{B 2}\right)$ where $\rho_{B 2}\left(x, z_{1}, z_{2}\right)$ is the reduced radius of curvature for the mating moment at the contact point of one pair, $\mathrm{B}_{2}$.

Fig.5a shows the line of contact (actions) $\xi$, the segment of pressure contact $\mathrm{E}_{1} \mathrm{E}_{2}$, the radii of basic circles $\mathrm{r}_{b 1}, \mathrm{r}_{b 2}$, the radii of the addendum circles $\mathrm{r}_{a 1}, \mathrm{r}_{a 2}$, the pitch on basic circles $\mathrm{p}_{b}$ and the pressure angle $\alpha_{w}, \varepsilon_{\alpha}-$ the tooth contact ratio.

Now we can compare the radius $\rho_{B 2}$ (x) with $\left.\rho_{B 2}\right|_{x_{1}=x_{2}=0}=\rho_{o}$ and build the non-dimensional function for the central and satellite wheels $z_{1} / z_{2}$.

$$
\kappa(x)=\frac{\rho_{B 2}(x)}{\rho_{o}}
$$

In geometrical sense, the strength of the tooth working surfaces depends only on the reduced radius of curvature and the value of function $\kappa(\mathrm{x})$ must not be less then 1 , taking proper corrections coefficients $\langle\mathrm{x}\rangle$.

The relation $\rho(\xi)$, well known in literature [8] and illustrated in Fig.5b, is presented by the formula

$$
\rho(\xi)=\xi \cdot\left(1-\frac{\xi}{l}\right)
$$




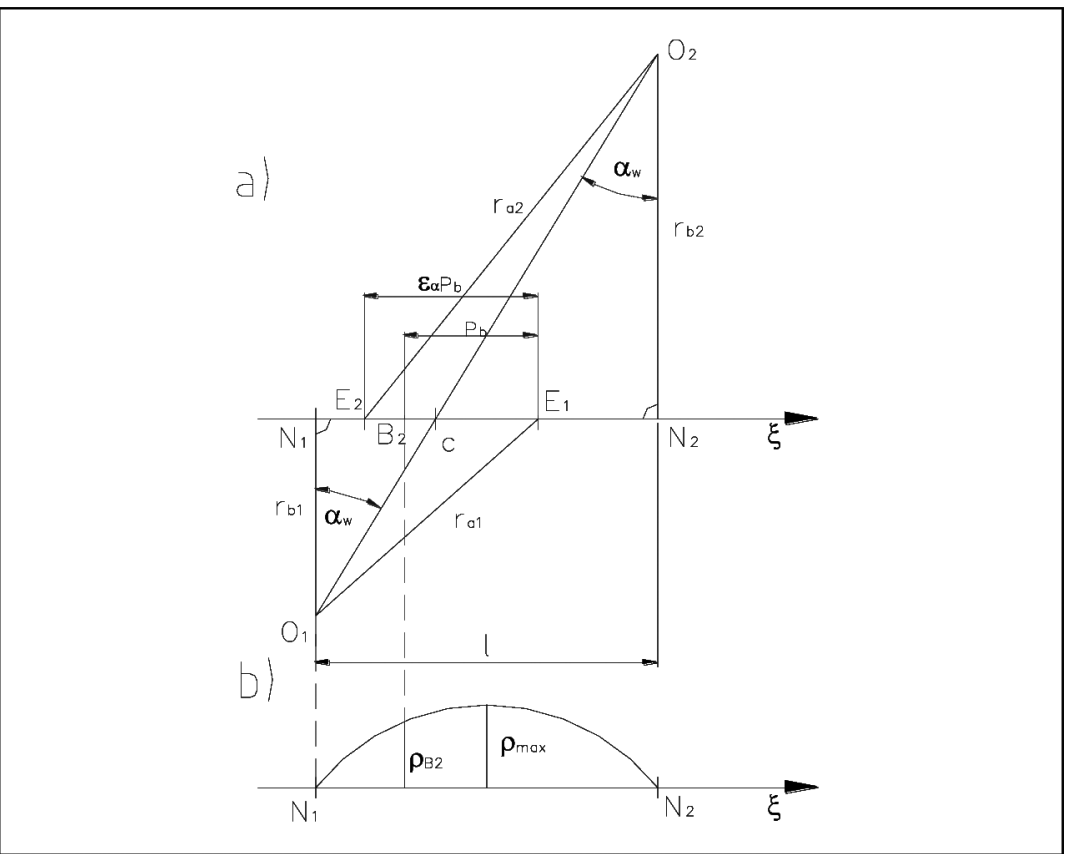

Fig. 5. Engagement of toothed wheels $\mathrm{z}_{1} / \mathrm{z}_{2}$, a) along the line of action $\xi$ at segment $E_{1} E_{2} \subset N_{1} N_{2}$, b) reduced radius of curvature along the line of contact $\rho(\xi)$

Let us transform the formula (15) to apply it to the teeth of matting wheels after replacing its values by the parameters of a toothed gear. Consequently $\kappa(\mathrm{x})$ can be written thus

$$
\begin{aligned}
& \rho_{B 2}(x)=\eta(x) \cdot(1-\eta(x)) \cdot \frac{l}{4} ; \eta(x)=\frac{\xi_{B}}{l} \\
& \rho_{o}=\eta_{o}\left(1-\eta_{o}\right) \cdot \frac{l_{o}}{4}
\end{aligned}
$$

Replacing,

$$
\xi_{B}=\sqrt{r_{a 1}^{2}-r_{b 1}^{2}}-p_{b} ; l=a \cdot \sin \left(\alpha_{w}\right)=a_{o} \cdot \cos (\alpha) \cdot \operatorname{tg}\left(\alpha_{w}\right)
$$

then substituting relations (19) into it

$$
\frac{p_{b}}{a_{o}}=\frac{2 \cdot \pi}{z_{1}+z_{2}} \cos (\alpha) ; \frac{r_{b 1}}{a_{o}}=\frac{z_{1}}{z_{1}+z_{2}} \cos (\alpha) ; \frac{r_{a 1}}{a_{o}}=\frac{z_{1}+2 \cdot\left(1+x_{1}\right)}{z_{1}+z_{2}}
$$


then we get $\eta(\mathrm{x})$ with restriction $<\mathrm{x}>$

$$
\begin{gathered}
\eta(x)=\frac{\sqrt{\left[z_{1}+2 \cdot\left(1+x_{1}\right)\right]^{2}-\left[\left(z_{1} \cos (\alpha)\right)\right]^{2}}-2 \cdot \pi \cos (\alpha)}{\left(z_{1}+z_{2}\right) \cdot \cos (\alpha) \cdot \tan \left(\alpha_{w}^{\prime}\right)} \\
\eta_{o}=\frac{\sqrt{\left[z_{1}+2\right]^{2}-\left[\left(z_{1} \cos (\alpha)\right)\right]^{2}}-2 \cdot \pi \cos (\alpha)}{\left(z_{1}+z_{2}\right) \cdot \cos (\alpha) \cdot \tan (\alpha)} \\
\cos \left(\alpha_{w}\right)=\frac{a}{a_{o}} \cos (\alpha) \\
x_{1}+x_{2}=c 1=\frac{\left\{\left[\tan \left(\alpha_{w}^{\prime}\right)-\alpha_{w}^{\prime}\right]-\tan (\alpha)+\alpha\right\} \cdot\left(z_{1}+z_{2}\right)}{2 \cdot \tan (\alpha)} \\
x_{1 \min } \leq x_{1} \leq x_{1 \max } \wedge x_{2 \min } \leq x_{2} \leq x_{2 \max }
\end{gathered}
$$

Substituting the equations (17), (20) into (15) we can obtain the function $\kappa\left(x_{1}, x_{2}\right)$ for the central and the satellite wheels $\mathrm{z}_{1} / \mathrm{z}_{2}$.

$$
\begin{aligned}
& \kappa(x)=A(x) \frac{1-\eta(x)}{1-\eta_{o}} \\
& A(x)=\frac{\sqrt{\left[z_{1}+2 \cdot\left(1+x_{1}\right)\right]^{2}-\left[\left(z_{1} \cos (\alpha)\right)\right]^{2}}-2 \cdot \pi \cos (\alpha)}{\sqrt{\left[z_{1}+2\right]^{2}-\left[\left(z_{1} \cos (\alpha)\right)\right]^{2}}-2 \cdot \pi \cos (\alpha)}
\end{aligned}
$$

In design calculations the stresses of the root of teeth $\sigma_{F}(x, z)$ determine the fatigue resistance of each toothed wheel; the formula (13) depends on the form factor of the tooth $Y_{F \alpha}(x, z)$.

The Form factor $Y_{F \alpha}(x, z)$ is determined by ISO [4] in the form of relations and diagrams referring to cutting tools parameters. The magnitude of this factor reaches the minimum value of about 1.9 when a standard tool rack has $\alpha=20^{\circ}, \mathrm{h}_{a o} / \mathrm{m}=1.25$, and $\rho / \mathrm{m}=0.2$ ), where $\rho$ - the radius of tools fillet.

Consequently, we build the non-dimensional function for determining the fatigue resistance of each toothed wheel

$$
\lambda(x)=\frac{1.9}{Y_{F \alpha}}
$$

At valuables region $<x>$ for each toothed wheel $z_{1}, z_{2}, z_{3}$ we can evaluate the fatigue strength when $\lambda(\mathrm{x})$ reaches the maximum value [2], [5].

\section{Examples of projects}

Case I, Fig.4 
We take under consideration a planetary gear with the data: $\mathrm{z}_{1}=24$, $\mathrm{z}_{2}=45, \mathrm{z}_{3}=114, \mathrm{y}=1, \alpha=20^{\circ}, \mathrm{m}=4$ according to Fig. 1 so that some restrictions concerning the proper number of the teeth $\mathrm{z}_{1} ; \mathrm{z}_{2} ; \mathrm{z}_{3}$ are satisfied. An analysis of strength needs a diagram $\lambda(\mathrm{x})$ for each wheel. On the basis of the ISO standard diagram [4] it is easy to build by parabolic interpolation functions such as in Fig. 6, which gives us an opportunity to find some different acceptable solutions. Table 1. contains six propositions: no.1 - a gear without corrections, no.2 - a gear with corrections P0, no.3,4,5 - a gear with correction $\mathrm{P}$ and the constant value of $\mathrm{C}=\mathrm{x}_{1}+\mathrm{x}_{2}$, and no.6 $-\mathrm{a}$ gear with correction $\mathrm{P}$ and the distance of axis $\mathrm{a} \neq \mathrm{a}_{o}$.

According to Table 1, the best solution (no.4) yields $\kappa=1.1403$ (Table 2) which means that the surface strength increases about $6.8 \%, \lambda_{1}$ changing from 0.69 to 0.81 , the fatigue strength of the central wheel increases about $17.3 \%$, other wheels have proper fatigue strength $\lambda_{2}=0.75, \lambda_{3}=0.81$. According to relations (9) and (10) $\alpha_{w}^{\prime}=21.475^{\circ} \alpha_{w}^{\prime \prime}=21.475^{\circ}$ and $\mathrm{r}_{w 2},=\mathrm{r}_{w 2}$ ". The Resultant dimensions of teeth engagement are presented in Table 3, and the proof of noninterference of the satellite and the sun wheels is presented in Table 4.

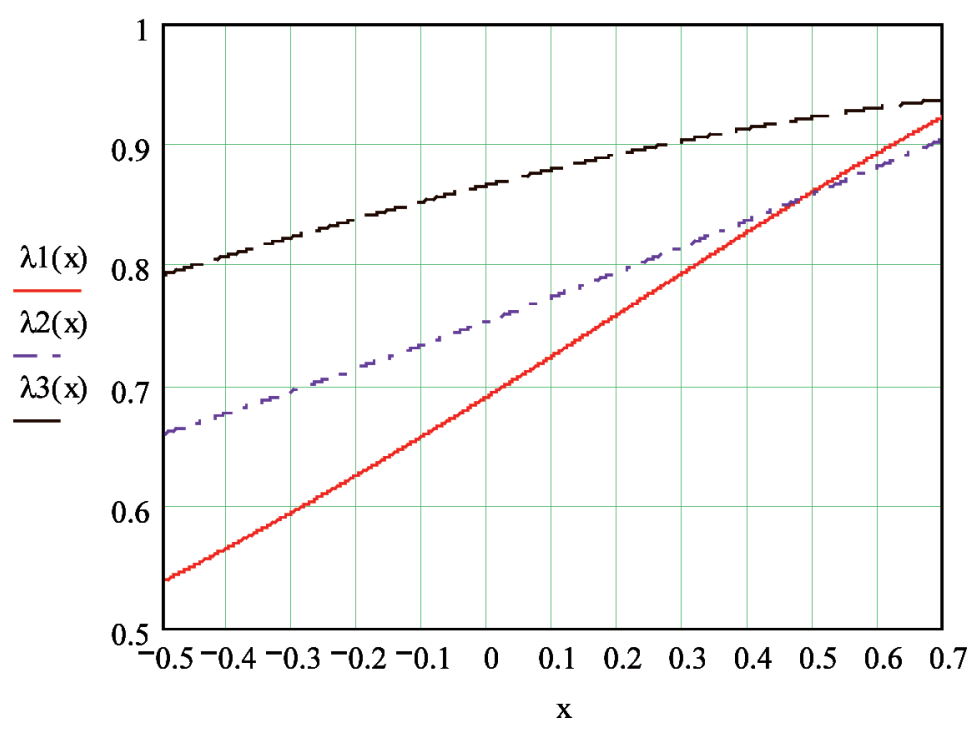

Fig. 6. Fatigue strength $\lambda(x)$ for wheels $z_{1}=24, z_{2}=45, z_{3}=114$ 
Table 1

\begin{tabular}{|c|c|c|c|c|c|c|c|}
\hline \multicolumn{7}{|c|}{$x_{1}+x_{2}=x_{2}+x_{3}=0 ; C=0 ;$ corrections $P 0$} \\
\hline No. & $\mathrm{x}_{3}$ & $\mathrm{x}_{2}$ & $\mathrm{x}_{1}$ & $\lambda_{3}$ & $\lambda_{2}$ & $\lambda_{1}$ & $\kappa$ \\
\hline 1 & 0 & 0 & 0 & 0.87 & 0.75 & 0.69 & 1.00 \\
\hline 2 & 0.12 & -0.12 & 0.12 & 0.88 & 0.73 & 0.73 & 1.037 \\
\hline 3 & -0.25 & 0 & 0.25 & 0.83 & 0.75 & 0.78 & 1.1139 \\
\hline 4 & -0.35 & 0 & 0.35 & 0.82 & 0.75 & 0.81 & 1.1403 \\
\hline 5 & -0.4 & 0.1 & 0.2 & 0.81 & 0.78 & 0.76 & 1.0933 \\
\hline \multirow{2}{*}{6} & -0.3567 & 0.1 & 0.1567 & 0.82 & 0.78 & 0.75 & 1.0759 \\
\cline { 2 - 8 } & \multicolumn{7}{|c|}{$\mathrm{a}=139.00 \mathrm{~mm} ; \mathrm{a}_{o}=138 \mathrm{~mm}$} \\
\hline
\end{tabular}

Table 2.

$$
\begin{aligned}
& \alpha_{\mathrm{W}^{\prime}}=0.3748 \quad \alpha=0.3491 \quad \mathrm{x}_{1}=0.35 \quad \mathrm{x}_{2}=0 \\
& \eta:=\frac{\sqrt{\left[z_{1}+2 \cdot\left(1+x_{1}\right)\right]^{2}-\left(z_{1} \cdot \cos (\alpha)\right)^{2}}-2 \cdot \pi \cdot \cos (\alpha)}{\left(z_{1}+z_{2}\right) \cdot \cos (\alpha) \cdot \tan \left(\alpha_{w^{\prime}}\right)} \quad \eta=0.3288 \\
& \eta_{\mathrm{o}}:=\frac{\sqrt{\left(\mathrm{z}_{1}+2\right)^{2}-\left(\mathrm{z}_{1} \cdot \cos (\alpha)\right)^{2}}-2 \cdot \pi \cdot \cos (\alpha)}{\left(\mathrm{z}_{1}+\mathrm{z}_{2}\right) \cdot \cos (\alpha) \cdot \tan (\alpha)} \quad \eta_{\mathrm{o}}=0.298 \\
& A:=\frac{\sqrt{\left[z_{1}+2 \cdot\left(1+x_{1}\right)\right]^{2}-\left(z_{1} \cdot \cos (\alpha)\right)^{2}}-2 \cdot \pi \cdot \cos (\alpha)}{\sqrt{\left(z_{1}+2\right)^{2}-\left(z_{1} \cdot \cos (\alpha)\right)^{2}}-2 \cdot \pi \cdot \cos (\alpha)} \quad A=1.1926 \\
& \kappa:=\mathrm{A} \cdot \frac{1-\eta}{1-\eta_{\mathrm{o}}} \quad \kappa=1.1403
\end{aligned}
$$

Table 3.

$$
\begin{array}{lllll}
\mathrm{z}_{1}=24 & \mathrm{z}_{2}=45 & \mathrm{z}_{3}=114 & \mathrm{~m}=4 & \\
\mathrm{r}_{\mathrm{w} 1}=48.4702 & \mathrm{r}_{\mathrm{w} 2^{\prime}}=90.8817 & \mathrm{r}_{\mathrm{w} 2}=90.8817 & \mathrm{r}_{\mathrm{w} 3}=230.2336 \\
\mathrm{r}_{\mathrm{b} 1}=45.1052 & \mathrm{r}_{\mathrm{b} 2}=84.5723 & \mathrm{r}_{\mathrm{b} 3}=214.2499 & \\
\mathrm{r}_{\mathrm{a} 1}=53.3519 & \mathrm{r}_{\mathrm{a} 2}=93.9519 & \mathrm{r}_{\mathrm{a} 3}=225.4487 & \alpha_{\mathrm{w}^{\prime} \mathrm{s}}=21.4752 \\
\mathrm{r}_{\mathrm{f} 1}=44.4 & \mathrm{r}_{\mathrm{f} 2}=85 & \mathrm{r}_{\mathrm{f} 3}=234.4003 & \alpha_{\mathrm{w}^{\prime \prime} \mathrm{s}}=21.4752 \\
\mathrm{r}_{1}=48 & \mathrm{r}_{2}=90 & \mathrm{r}_{3}=228 & \mathrm{a}_{\mathrm{o} 12}=138 & \mathrm{a}_{\mathrm{o} 23}=138 \\
\mathrm{x}_{1}=0.35 & \mathrm{x}_{2}=0 & \mathrm{x}_{3}=-0.3501 & \mathrm{a}=139.3519
\end{array}
$$


Table 4.

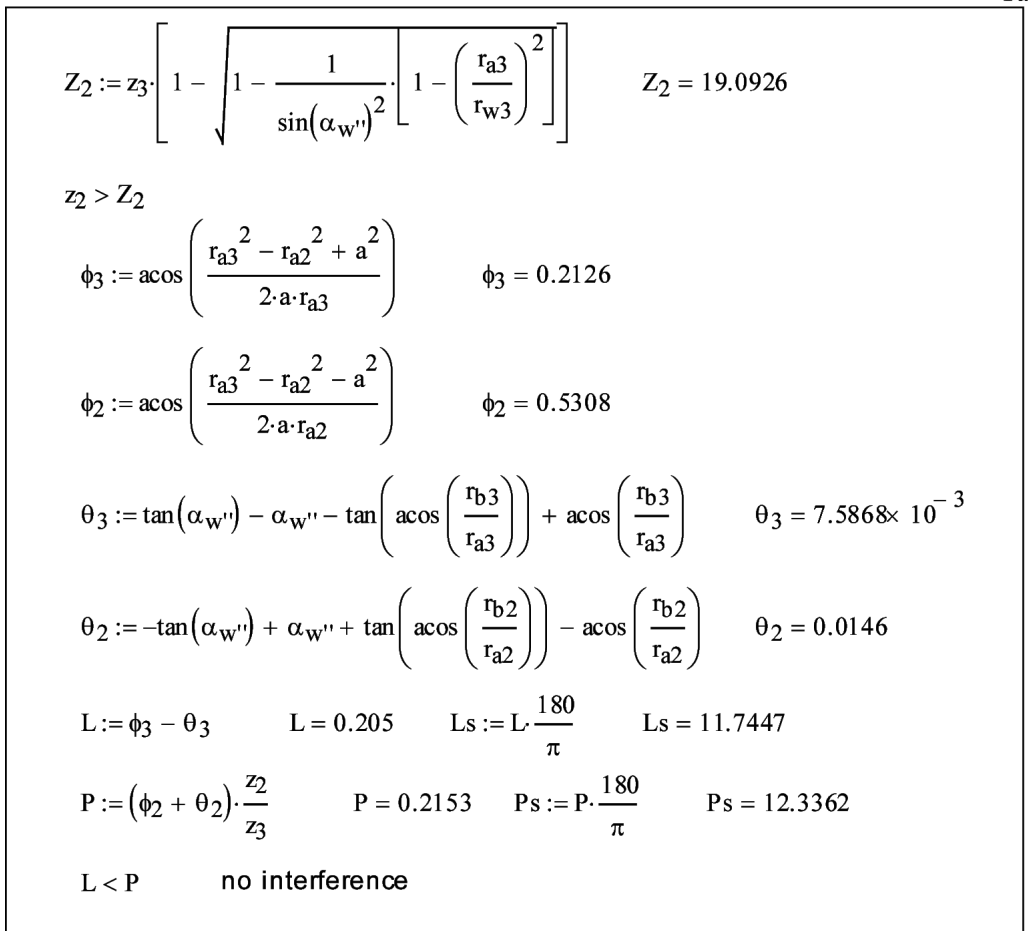

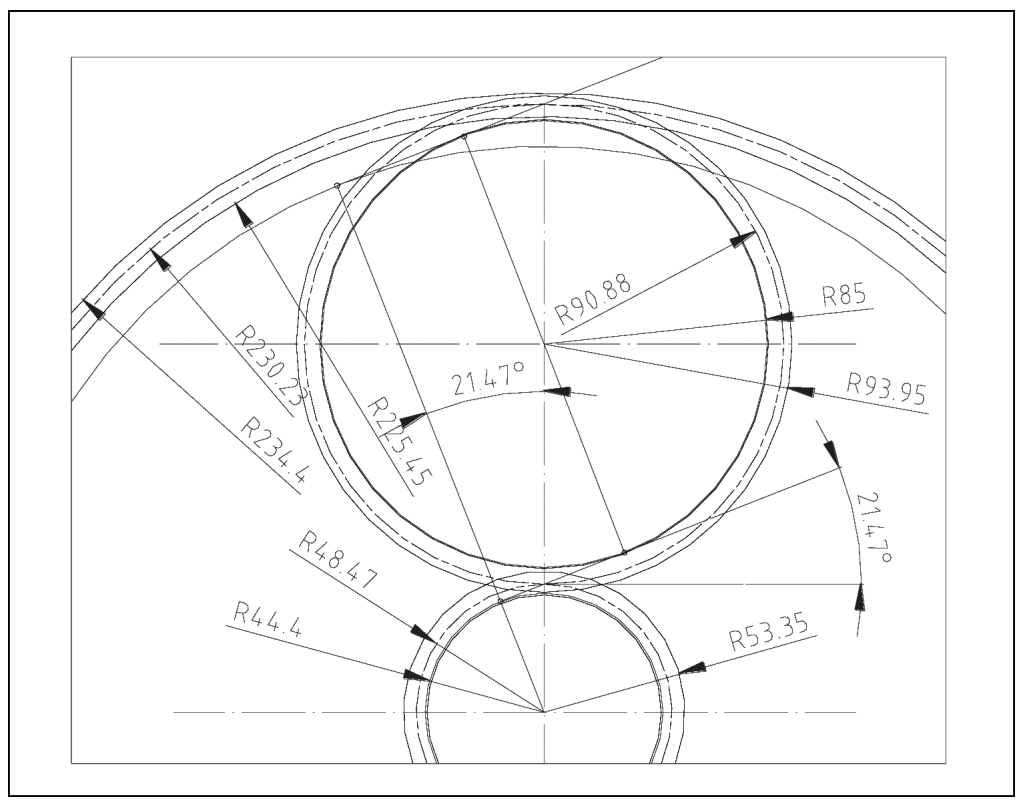

Fig. 7. Geometric parameters of designed gears $z_{1}=24, z_{2}=45, z_{3}=114$ 
The fundamental geometric parameters of the designed gears are shown in Fig. 7 and the geometry of the cooperating toothed wheels is demonstrated in Fig. 8.

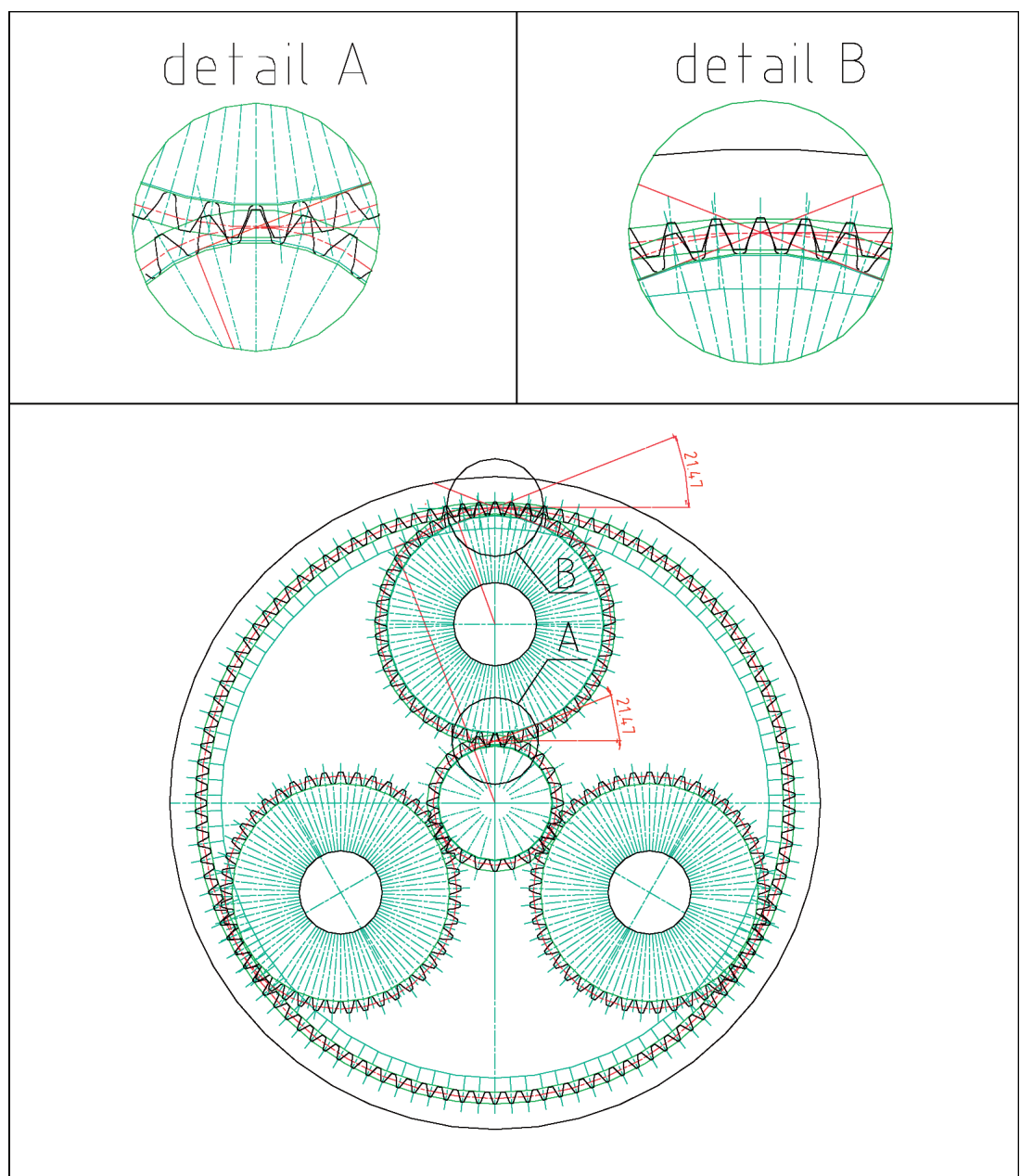

Fig. 8. Geometry of cooperating planetary toothed wheels $\mathrm{z}_{1}=24, \mathrm{z}_{2}=45, \mathrm{z}_{3}=114$

Case II, Fig.4

We take under consideration a planetary gear with the data: $\mathrm{z}_{1}=24$, $\mathrm{z}_{2}=46, \mathrm{z}_{3}=117, \mathrm{y}=1, \alpha=20^{\circ}, \mathrm{m}=4$ according to Fig. 1 so that some restrictions concerning the proper number of the teeth $\mathrm{z}_{1} ; \mathrm{z}_{2} ; \mathrm{z}_{3}$ are satisfied. An analysis of strength needs a diagram $\lambda(\mathrm{x})$ for each wheel. On the basis of the ISO standard [4], a diagram such as in Fig. 9, gives us an opportunity to find some acceptable solutions. Table 5 contains propositions with only the correction $\mathrm{P}$ possible, as was mentioned before $\alpha_{w}, \neq \alpha_{w}$, and $\mathrm{r}_{w 2}, \neq$ $\mathrm{r}_{w 2}$ ". In this case, it is more convenient to assume a different distance of the 
axis "a", taking $\mathrm{x}_{2}>0.1$ (Fig. 1) and then checking the results $\lambda_{1}, \lambda_{2}, \lambda_{3}, \kappa$ the condition of noninterference of the satellite and the sun wheels, and the fulfillment of inequalities (1) and (2).

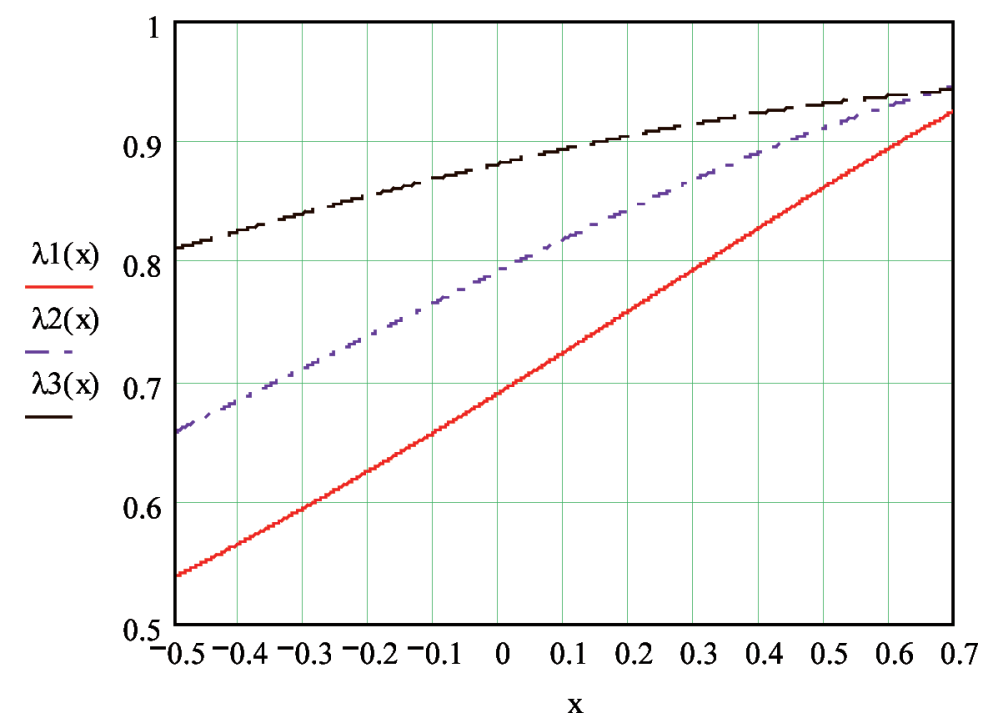

Fig. 9. Fatigue strength $\lambda(x)$ for wheels $z_{1}=24, z_{2}=46, z_{3}=117$

Table 5 .

\begin{tabular}{|c|c|c|c|c|c|c|c|}
\hline \multicolumn{8}{|c|}{$x_{1}=C 1-x_{2} ; x_{3}=C 2-x_{2} ;$ corrections $P$} \\
\hline No. & $\mathrm{x}_{3}$ & $\mathrm{x}_{2}$ & $\mathrm{x}_{1}$ & $\lambda_{3}$ & $\lambda_{2}$ & $\lambda_{1}$ & $\kappa$ \\
\hline \multirow{2}{*}{1} & 0.0233 & 0.1 & 0.2896 & 0.88 & 0.82 & 0.79 & 1.1284 \\
\cline { 2 - 8 } & \multicolumn{7}{|c|}{$\mathrm{a}=141.50 \mathrm{~mm} ; \mathrm{a}_{o 12}=140 \mathrm{~mm} ; \mathrm{a}_{o 23}=142 \mathrm{~mm}$} \\
\hline \multirow{2}{*}{2} & -0.1 & 0.1 & 0.4257 & 0.87 & 0.82 & 0.83 & 1.1792 \\
\cline { 2 - 7 } & 0.3266 & 0.2 & 0.4647 & 0.84 & 0.84 & 0.84 & 1.2032 \\
\hline \multirow{2}{*}{3} & $-0.32 .00 \mathrm{~mm} ; \mathrm{a}_{o 12}=140 \mathrm{~mm} ; \mathrm{a}_{o 23}=142 \mathrm{~mm}$ \\
\cline { 2 - 7 } & \multicolumn{7}{|c|}{$\mathrm{a}=142.50 \mathrm{~mm} ; \mathrm{a}_{o 12}=140 \mathrm{~mm} ; \mathrm{a}_{o 23}=142 \mathrm{~mm}$} \\
\hline
\end{tabular}

According to Table 5, the best solution (no.3) yields $\kappa=1.2032$ that means the surface strength increases about $9.8 \%$, and all the wheels have the proper fatigue strength $\lambda_{1}=\lambda_{2}=\lambda_{3}=0.84$. On the basis of relation (9) and (10) we obtain $\alpha_{w}=22.6005^{\circ} \alpha_{w}^{\prime \prime}=20.5452^{\circ}$, and the procedure of computing the coefficient of corrections is presented in Table 6 . 
Table 6.

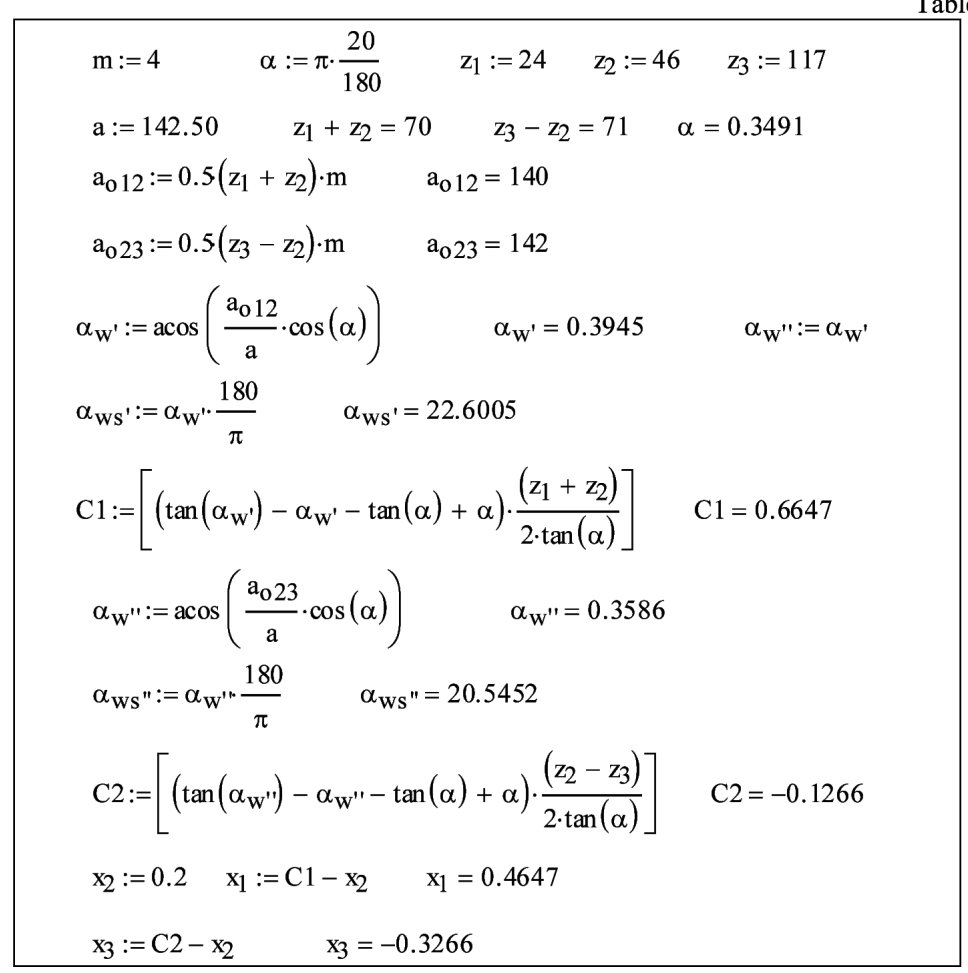

Table 7.

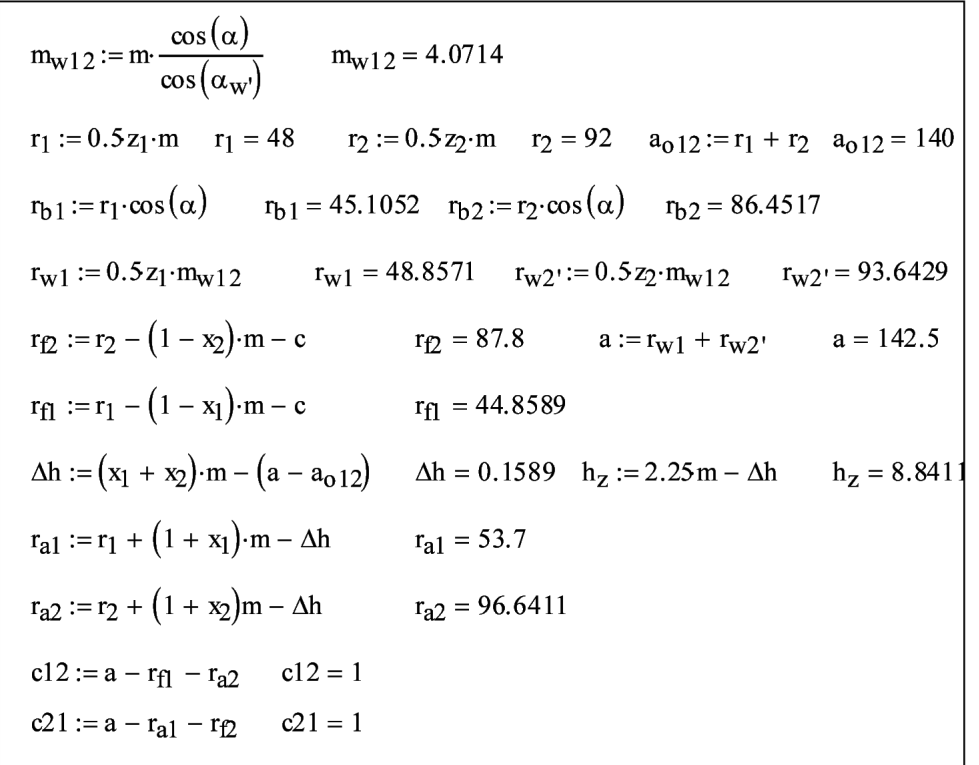


The resultant dimensions of teeth engagement $z_{1} / z_{2}$ i.e. the radii of the diametric circle, the basic circle, the rolling circle, the addendum and the dedendum circle, and also the tip clearance c12 i c21 are presented in Table 7. In a similar way, the resultant dimensions of the teeth engagement $z_{2} / z_{3}$ are calculated additionally to verify the thickness of the teeth in the rolling circles $\mathrm{s}_{2}, \mathrm{~s}_{3}$. The results are presented in Table 8 . The collected results of the dimensions of teeth engagement are presented in Table 9; Fig. 10 illustrates the main geometric parameters of the designed planetary gears.

Table 8.

$$
\begin{aligned}
& \mathrm{r}_{3}:=0.5 \mathrm{z}_{3} \cdot \mathrm{m} \quad \mathrm{r}_{3}=234 \quad \mathrm{r}_{2}:=0.5 \mathrm{z}_{2} \cdot \mathrm{m} \quad \mathrm{r}_{2}=92 \\
& \mathrm{r}_{\mathrm{b} 3}:=\mathrm{r}_{3} \cdot \cos (\alpha) \quad \mathrm{r}_{\mathrm{b} 3}=219.8881 \mathrm{r}_{\mathrm{b} 2}:=\mathrm{r}_{2} \cdot \cos (\alpha) \quad \mathrm{r}_{\mathrm{b} 2}=86.4517 \\
& \mathrm{~m}_{\mathrm{w} 23}:=\frac{2 \mathrm{a}}{\mathrm{z}_{3}-\mathrm{z}_{2}} \quad \mathrm{~m}_{\mathrm{w} 23}=4.0141 \\
& \mathrm{C} 2:=\left(\tan \left(\alpha_{w^{\prime \prime}}\right)-\tan (\alpha)-\alpha_{w^{\prime \prime}}+\alpha\right) \cdot \frac{\left(z_{2}-z_{3}\right)}{2 \cdot \tan (\alpha)} \quad \mathrm{C} 2=-0.1266 \\
& \mathrm{x}_{2}=0.2 \quad \mathrm{x}_{3}:=\mathrm{C} 2-\mathrm{x}_{2} \quad \mathrm{x}_{3}=-0.3266 \quad \alpha=0.3491 \\
& \mathrm{~m}_{\mathrm{w} 23}:=\mathrm{m} \cdot \frac{\cos (\alpha)}{\cos \left(\alpha_{\mathrm{w}^{\prime \prime}}\right)} \quad \mathrm{m}_{\mathrm{w} 23}=4.0141 \quad \alpha_{\mathrm{w}^{\prime \prime}}=0.3586 \quad \alpha_{\mathrm{w}^{\prime}}=0.3945 \\
& \mathrm{r}_{\mathrm{w} 3}:=0.5 \mathrm{z}_{3} \cdot \mathrm{m}_{\mathrm{w} 23} \quad \mathrm{r}_{\mathrm{w} 3}=234.8239 \quad \mathrm{r}_{\mathrm{w} 2}{ }^{\prime}:=0.5 \mathrm{z}_{2} \cdot \mathrm{m}_{\mathrm{w} 23} \quad \mathrm{r}_{\mathrm{w} 2 "}=92.3239 \\
& \mathrm{a}_{\mathrm{o} 23}:=0.5\left(\mathrm{z}_{3}-\mathrm{z}_{2}\right) \cdot \mathrm{m} \quad \mathrm{a}_{\mathrm{o} 23}=142 \quad \mathrm{a}:=\mathrm{r}_{\mathrm{w} 3}-\mathrm{r}_{\mathrm{w} 2}{ }^{\prime \prime} \quad \mathrm{a}=142.5 \\
& \mathrm{a}_{\mathrm{o} 12}:=0.5\left(\mathrm{z}_{1}+\mathrm{z}_{2}\right) \cdot \mathrm{m} \quad \mathrm{a}_{\mathrm{o} 12}=140 \quad \mathrm{c}:=0.25 \mathrm{~m} \quad \mathrm{c}=1 \\
& r_{\mathrm{f} 3}:=r_{3}+\left(1-x_{3}\right) \cdot m+c \quad r_{f 3}=240.3066 \quad h_{a 3}:=\left(1+x_{3}\right) \cdot m \quad h_{a 3}=2.6934 \\
& r_{\mathfrak{f} 2}:=r_{2}-\left(1-x_{2}\right) \cdot m-c \quad r_{f 2}=87.8 \quad h_{f 3}:=\left(1-x_{3}\right) \cdot m+c \quad h_{f 3}=6.3066 \\
& \mathrm{~h}_{\mathrm{Z}}:=2.25 \mathrm{~m}-\Delta \mathrm{h} \quad \mathrm{h}_{\mathrm{z}}=8.8411 \quad \Delta \mathrm{h}:=0.0267 \\
& \mathrm{r}_{\mathrm{a} 3}:=\mathrm{r}_{\mathrm{f} 3}-\mathrm{h}_{\mathrm{z}} \quad \mathrm{r}_{\mathrm{a} 3}=231.4655 \quad \mathrm{r}_{\mathrm{a} 2}:=\mathrm{r}_{\mathrm{f} 2}+\mathrm{h}_{\mathrm{z}} \quad \mathrm{r}_{\mathrm{a} 2}=96.6411 \\
& \mathrm{c} 23:=\mathrm{r}_{\mathrm{f} 3}-\mathrm{a}-\mathrm{h}_{\mathrm{z}}-\mathrm{r}_{\mathrm{f} 2} \quad \mathrm{c} 23=1.1655 \\
& \mathrm{c} 32:=\mathrm{r}_{\mathrm{f} 3}-\mathrm{r}_{\mathrm{a} 2}-\mathrm{a} \quad \mathrm{c} 32=1.1655 \\
& \mathrm{~s}_{2}:=2 \cdot \mathrm{r}_{\mathrm{w} 2}\left(\frac{\frac{\pi}{2}+2 \mathrm{x}_{2} \cdot \tan (\alpha)}{\mathrm{z}_{2}}+\tan (\alpha)-\alpha-\tan \left(\alpha_{\mathrm{w}^{\prime \prime}}\right)+\alpha_{\mathrm{w}^{\prime \prime}}\right) \\
& \mathrm{s}_{2}=6.65 \\
& \mathrm{~s}_{3}:=2 \cdot \mathrm{r}_{\mathrm{w} 3} \cdot\left(\frac{\frac{\pi}{2}+2 \mathrm{x}_{3} \cdot \tan (\alpha)}{\mathrm{z}_{3}}+\tan \left(\alpha_{\mathrm{w}^{\prime \prime}}\right)-\alpha_{\mathrm{w}^{\prime \prime}}-\tan (\alpha)+\alpha\right) \\
& \mathrm{s}_{3}=5.9607 \quad \mathrm{~s}_{3}+\mathrm{s}_{2}=12.6106 \quad \pi \cdot \mathrm{m}_{\mathrm{w} 23}=12.6106
\end{aligned}
$$


Table 9.

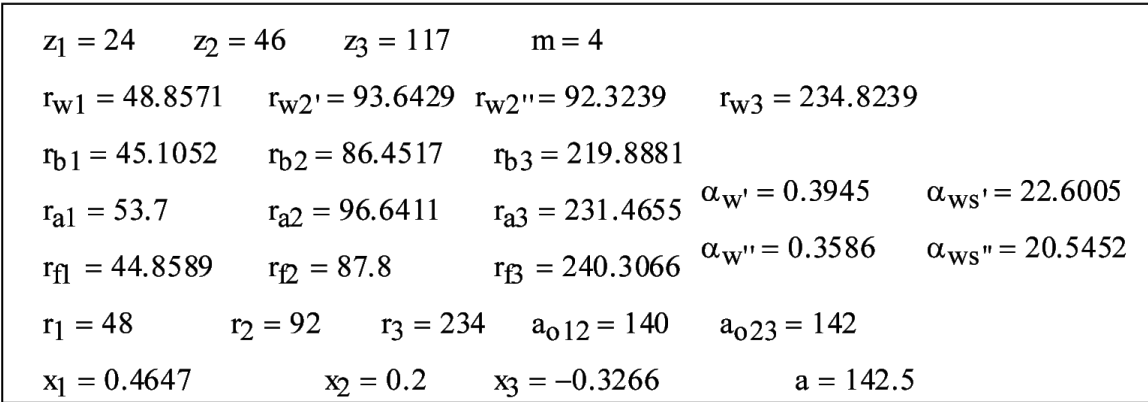

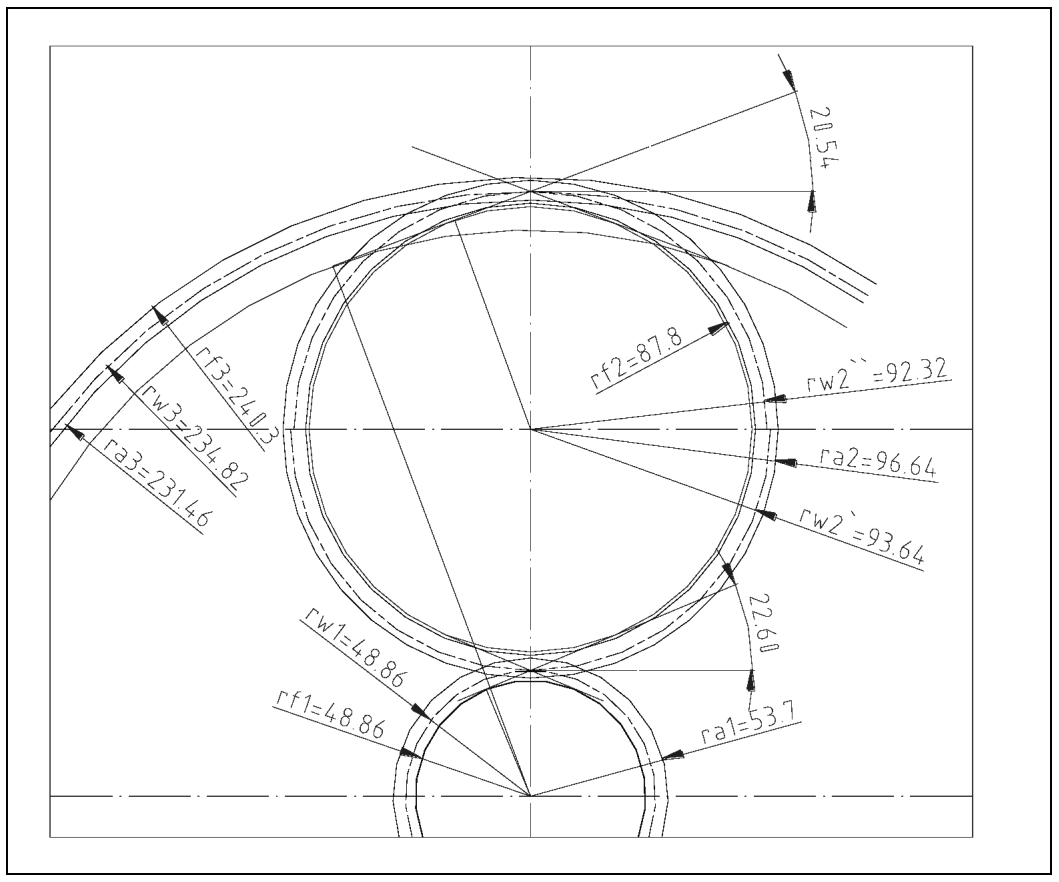

Fig. 10. Geometric parameters of designed gears $\mathrm{z}_{1}=24, \mathrm{z}_{2}=46, \mathrm{z}_{3}=117$

\section{Conclusion}

In this study, we have presented a new design procedure for determining modification coefficients of the toothed wheels of a planetary gear train with internal conjunction of teeth. It is possible to obtain a higher load-carrying capacity, which depends also on the correction coefficients.

We have proposed the procedure for planetary gears with internal engagements, in which the non-dimensional strength function $\lambda(\mathrm{x}, \mathrm{z})$ and $\kappa(\mathrm{x}, \mathrm{z})$ 
is used. In this way, the new allowable geometrical solution of a planetary gear can be evaluated.

The described relations gives us the opportunity to compute all geometrical parameters of the cooperating wheels, which can be manufactured on an industrial scale.

The presented procedure and the projects may be useful for developing a more effective, optimal computer procedure.

Manuscript received by Editorial Board, March 05, 2012;

final version, May 31, 2012.

\section{REFERENCES}

[1] Podstawy Konstrukcji Maszyn, pod redakcja Marka Dietricha, PWN, Warszawa, 1995.

[2] Dziama L., Michniewicz M., Niedzwiedzki A.: Przekładnie zębate. PWN, Warszawa, 1989.

[3] Ochęduszko K.: Koła zębate, t. 1, WNT, Warszawa, 1990.

[4] PN-ISO 6336-1/2/3.

[5] Kasperek T., Ryś J.: Dobór korekcji w przekładni planetarnej o identycznej geometrii satelitów, Czasopismo Techniczne, z.7 1-M/2010.

[6] Ryś J., Kasperek T.: Geometria przekładni planetarnej z zazębieniem zewnętrznym o uproszczonej technologii, Czasopismo Techniczne, z. 1 1-M/2006.

[7] Ryś J., Sendyka B.: Ustalenie obszaru rozwiązywalności II poprawki kół o zarysach ewolwentowych, Czasopismo Techniczne, z. 6, 1978.

[8] Ryś J., Skrzyszowski Z.: Podstawy konstrukcji maszyn, t. 2, Wyd. PK, Kraków 2003.

[9] Ryś J., Kasperek T.: Project of planetary gear with the same geometry of a satellite wheel, The Archive of Mechanical Engineering, vol. LV, 2008, 3, p. 265-273.

Metoda doboru współczynników korekcji w zębatych przekładniach planetarnych

$$
\text { Streszczenie }
$$

Celem pracy jest prezentacja procedury obliczeniowej określającej geometrię i wpływ współczynników korekcji na wytrzymałość postaciową i kontaktową powierzchni zębów w planetarnych przekładniach zębatych z zazębieniem wewnętrznym kół satelitów. Rozważane są przypadki, gdy zerowe odległości osi koła centralnego i satelitów są równe, lub nie zerowej odległości osi satelitów i koła słonecznego. Wymiary geometryczne będą opisane na bazie dopuszczalnej korekcji oraz warunków w odniesieniu do wymagań normy ISO oraz literatury. Procedura obliczeń zaprezentowana na przykładach może być zastosowana do dowolnej przekładni planetarnej o innym kinematycznym połączeniu kół. 